\title{
EFFECTS OF MELANOCORTIN-4 RECEPTOR GENE ON GROWTH AND MEAT TRAITS IN PIGS RAISED IN RUSSIA
}

\author{
${ }^{1}$ Klimenko, A., ${ }^{2}$ A. Usatov, ${ }^{1}$ Lyubov Getmantseva, ${ }^{1}$ Yu Kolosov, \\ ${ }^{1}$ O. Tretyakova, ${ }^{1}$ S. Bakoev, ${ }^{3}$ O. Kostjunina and ${ }^{3}$ N. Zinovieva \\ ${ }^{1}$ Don State Agrarian University, Persianovskiy, Russia \\ ${ }^{2}$ Southern Federal University, Rostov-on-Don, Russia \\ ${ }^{3}$ GNU VNIVIzh Rossel'khozakademii-State Research Institution the All-Russian Research, \\ Institute of Animal Breeding at the Russian Agricultural Academy, Dubrovicy, Russia
}

Received 2014-01-21; Revised 2014-01-25; Accepted 2014-02-11

\begin{abstract}
The Melanocortin-4 Receptor (MC4R), a G-protein coupled receptor, is implicated in mediating the effect of leptin on food intake and energy balance. A previous candidate gene study reported an association between an MC4R polymorphism (Asp298Asn) and growth and meat productive traits of pigs. The aim of this work was to determine frequencies of the MC4R/Taq I genotypes and alleles in Danish Landrace (LD), Canadian Landrace (LC) and crossbred pigs Danish Landrace $\times$ Canadian Landrace $(\mathrm{LD} \times \mathrm{LC})$ in breeding Cent "Plemzavod Jubilee" (Tyumen) Russia and to estimate their associations with some growth and meat traits. The polymorphism was identified by PCR-RFLP method. The traits studied were: Number of days to 100-kg, Average Daily Gain (ADG), Backfat Thickness (BFT), average daily Feed Intake (FI) and Length of Body (LB). In the all test groups we found a higher frequency of $\mathrm{G}$ allele (0.71) compared with the A allele (0.29). The results of present study suggest that the MC4R gene contributes to Days to $100 \mathrm{~kg}$, ADG and BF. The heterozygous genotype AG was favorable in LD breed. The significant effects of-1.43 (LD male) and -2.81(LD female) for Days to $100 \mathrm{~kg}$ and of +61.17 (LD male) and +26.3 (LD female) for ADG were calculated. The homozygous genotype GG was favorable in crossbred $\mathrm{LD} \times \mathrm{LC}$. The significant effects of +74.2 for $\mathrm{ADG}$ and -1.5 for BF were calculated. Therefore, the data support a role for the MC4R Asp298Asn polymorphism in the genetic basis of economically important traits in pigs of Russia. Further research is needed to determine the effect of this gene on growth, meat and reproduction traits in pigs of different breeds and crosses.
\end{abstract}

Keywords: Gene, MC4R, Pigs, Growth, Meat Productive Traits

\section{INTRODUCTION}

Genetic studies in animals have contributed to the identification of the main genetic causes of obesity (Tenesa et al., 2009; Hinney et al., 2010; Hebebrand et al., 2013; Kalogeropoulos, 2013; Khan et al., 2014). Particular interest among the candidates of signaling molecules involved in the regulation of energy homeostasis is Melanocortin-4 Receptor (MC4R). MC4R is responsible for the leptin signal between food intake and body weight (Benoit et al., 2000;
Loos et al., 2008; Wan et al., 2012; Kesmanee, 2013; Lisyova et al., 2014). Molecular studies in the departments of the paraventricular nucleus of the hypothalamus revealed gene expression of MC4R, which encodes a second type of neuronal melanocortin receptors (Gantz et al., 1993). These studies led to the assumption that the participation of the melanocortin-4 receptor in the regulation of hypothalamo-pituitary axis (Mountjoy et al., 1994).

The porcine gene Melanocortin-4 Receptor (MC4R) was mapped on chromosome 1q22-q27. Kim et al.

Corresponding Author: Lyubov Getmantseva, Don State Agrarian University, Persianovskiy, Russia 
(2000) identified the missense mutation p.Asp298Asn (AF087937: C.746G A) in a highly conservative region of MC4R which was associated with feed intake and carcass fatness traits in pigs. The effect of MC4R polymorphism Asp298Asn on feed intake, growth rate and meat traits has been confirmed in several populations of pigs with different genetic backgrounds (Kim et al., 2000; Houston et al., 2004; Jokubka et al., 2006; Ovilo et al., 2006; Piorkowska et al., 2010; Switonski et al., 2010). However, some studies did not detect any significant effects of this gene polymorphism on production traits (Park et al., 2002; Maagdenberg et al., 2007). Perhaps these results are related to genetic features associated with the breed of the animals.

The aim of our work was to determine frequencies of the MC4R/Taq I genotypes and alleles in Danish Landrace, Canadian Landrace and crossbred pigs Danish Landrace $\mathrm{x}$ Canadian Landrace from Russia and to estimate their associations with some growth and meat traits.

\section{MATERIALS AND METHODS}

\subsection{Animals}

A total of 398 pigs were included in the analysis. There were 186 Danish Landrace pigs (LD) (66 meal ( $ठ)$ and 120 female (o)); 80 Canadian Landrace (LC) (56 meal $(\hat{\bigcirc})$ and 24 female $(\phi))$ and 132 female crossbred pigs Danish Landrace $\times$ Canadian Landrace $(\mathrm{LD} \times \mathrm{LC})$. All the pigs were from breeding center Yubileiny, Tyumen, Russia. All individuals were reared in the same conditions and fed with standard feed.

\subsection{Studied Traits}

The animals were recorded for the following traits: The number of days to $100-\mathrm{kg}$ (days to $100 \mathrm{~kg}$ ), Average Daily Gain (ADG), Feed Intake (FI) and Backfat Thickness (BFT). All traits were obtained according to the results of growing up to $100 \mathrm{~kg}$.

\subsection{Genotyping}

DNA was taken from samples of animal tissue (hair) of animals. Genotyping was performed by PCRRFLP method described by Kim et al. (2000) with subsequent primers:

\section{FOR: 5'-TAC CCT GAC CAT CTT GAT TG-3' 5'-ATA GCA ACA GAT GAT CTC TTT G-3'}

After amplification, the PCR product was digested with Taq1.

\subsection{Statistical Analysis}

Frequencies of the MC4R genotypes were calculated as a genotype percentage in the population. Analysis of the gene effect to observed traits were analyzed using a linear model. The model was:

$$
\text { Yijkl }=\mu+\mathrm{Gi}+\operatorname{Sexj}+\mathrm{MC} 4 \mathrm{Rk}+\mathrm{eijkl}
$$

Where:

Yijkl= The phenotypic record

$\mu \quad=$ The general mean

$\mathrm{Gi}=$ The effect of genetic group of sow $(\mathrm{i}=\mathrm{LD}$, $\mathrm{LC}, \mathrm{LD} \times \mathrm{LC}$ )

Sexj = The effect of $\operatorname{sex}(\mathrm{j}=\mathrm{F}, \mathrm{M})$

MC4Rk = The effect of MC4R genetype $(\mathrm{k}=\mathrm{AA}, \mathrm{AG}$, GG)

Eijkl $=$ The random error

\section{RESULTS}

We tested 186 pigs of Danish Landrace, 80 pigs of Canadian Landrace and 132 crossbred pigs (Danish Landrace $\times$ Canadian Landrace) for the Taq1 polymorphism in the MC4R gene by PCR-RFLP. The frequencies of alleles and genetic structure in the MC4R gene are shown in Table 1. Lower frequencies of the AA genotype were found in tested pig. We did not find any AA genotype in the group female LC. In the all test groups we found a higher frequency of $\mathrm{G}$ allele $(0.71)$ compared with the A allele (0.29).

Effects of the MC4R genotypes on Days to $100 \mathrm{~kg}$, ADG, feed intake, backfat thickness and length of body are presented in Table 2.

Table 1. The genetic structure and frequencies of alleles at polymorphism within MC4R gene in pigs of Danish Landrace, Canadian Landrace and crossbred LD $\times$ LC

\begin{tabular}{|c|c|c|c|c|c|}
\hline \multirow[b]{2}{*}{ Breed } & \multicolumn{3}{|c|}{ Genotypes (\%) } & \multicolumn{2}{|c|}{ Allele } \\
\hline & AA & $\mathrm{AG}$ & GG & A & G \\
\hline$\partial^{7} \mathrm{LD}(\mathrm{n}=66)$ & 6.2 & 49.2 & 44.6 & 0.31 & 0.70 \\
\hline$+\mathrm{LD}(\mathrm{n}=120)$ & 10.8 & 41.7 & 47.5 & 0.32 & 0.69 \\
\hline$\delta^{7} \mathrm{LC}(\mathrm{n}=56)$ & 8.9 & 41.1 & 50.0 & 0.30 & 0.71 \\
\hline qLC $(n=24)$ & 0.0 & 50.0 & 50.0 & 0.25 & 0.75 \\
\hline $\mathrm{LD} \times \mathrm{LC}(\mathrm{n}=132)$ & 6.3 & 40.6 & 53.1 & 0.26 & 0.74 \\
\hline $\mathrm{N}=398$ & 6.4 & 44.5 & 49.1 & 0.29 & 0.71 \\
\hline
\end{tabular}


Klimenko, A. et al. / American Journal of Agricultural and Biological Sciences 9 (2): 232-237, 2014

Table 2. Effect of the MC4R genotypes (least square means \pm standard error) on the number of days to $100-\mathrm{kg}$ (days to $100 \mathrm{~kg}$ ), Average Daily Gain (ADG), Feed Intake (FI), backfat thickness (BF) and length of body (LB) in LD, LC and LD×LC pigs

\begin{tabular}{|c|c|c|c|}
\hline \multirow[b]{2}{*}{ MC4R } & \multicolumn{3}{|c|}{ Days of $100 \mathrm{~kg}$ (days) } \\
\hline & AA & AG & GG \\
\hline \multicolumn{4}{|l|}{ Danish Landrace (male) } \\
\hline SM & 144.14 & $142.94^{*}$ & 144.59 \\
\hline SE & 1.55 & 0.78 & 0.75 \\
\hline \multicolumn{4}{|l|}{ Danish Landrace (female) } \\
\hline SM & 163.23 & $161.30^{* * *}$ & 165.00 \\
\hline SE & 0.62 & 1.11 & 1.00 \\
\hline \multicolumn{3}{|l|}{ Canadian Landrace (male) } & \\
\hline $\begin{array}{l}\text { SM } \\
\text { SE }\end{array}$ & $\begin{array}{r}141.32 \\
0.53\end{array}$ & $\begin{array}{r}141.40 \\
0.90\end{array}$ & $\begin{array}{r}141.30 \\
0.81\end{array}$ \\
\hline \multicolumn{4}{|l|}{ Canadian Landrace (female) } \\
\hline SM & & 164.30 & 160.21 \\
\hline $\mathrm{SE}$ & & 2.18 & 2.19 \\
\hline \multicolumn{4}{|l|}{ Danish Landrace x Canadian Landrace (female) } \\
\hline & & 163.40 & 159.30 \\
\hline SE & & 2.28 & 3.25 \\
\hline \multicolumn{4}{|l|}{ ADG (g) } \\
\hline \multicolumn{4}{|l|}{ Danish Landrace (male) } \\
\hline $\begin{array}{l}\text { SM } \\
\text { SE }\end{array}$ & $\begin{array}{r}1067.57 \\
14.89\end{array}$ & 18.74 & 16.15 \\
\hline \multicolumn{4}{|l|}{ Danish Landrace (female) } \\
\hline SM & 860.69 & $865.44^{* * *}$ & 817.51 \\
\hline $\mathrm{SE}$ & 14.09 & 12.30 & 12.41 \\
\hline \multicolumn{4}{|l|}{ Canadian Landrace (male) } \\
\hline SM & 1112.88 & 1097.41 & 1114.91 \\
\hline SE & 11.98 & 17.31 & 15.91 \\
\hline \multicolumn{3}{|l|}{ Canadian Landrace (female) } & \\
\hline $\begin{array}{l}\text { SM } \\
\text { SE }\end{array}$ & & $\begin{array}{r}874.91 \\
24.06\end{array}$ & $\begin{array}{r}844.21 \\
28.99\end{array}$ \\
\hline \multicolumn{4}{|l|}{$\begin{array}{l}\text { Danish Landrace } x \text { Canadian Landrace (female) } \\
\text { Da }\end{array}$} \\
\hline SM & & 768.40 & $842.60^{*}$ \\
\hline SE & & 20.70 & 21.50 \\
\hline \multicolumn{4}{|l|}{ FI (kg) } \\
\hline Danish Landrace (male) & & & \\
\hline SM & 2.57 & 2.60 & 2.62 \\
\hline $\begin{array}{l}\text { SE } \\
\text { Canadian Landrace (male) }\end{array}$ & 0.06 & 0.05 & 0.05 \\
\hline $\begin{array}{l}\text { Canadian Landrace (male) } \\
\text { SM }\end{array}$ & & & 250 \\
\hline $\begin{array}{l}\text { SM } \\
\text { SE }\end{array}$ & $\begin{array}{l}2.55 \\
0.03\end{array}$ & $\begin{array}{l}2.58 \\
0.04\end{array}$ & 0.04 \\
\hline BF (mm) & & & \\
\hline Danish Landrace (male) & & & \\
\hline SM & 10.29 & 10.81 & 10.69 \\
\hline SE & 0.61 & 0.47 & 0.40 \\
\hline Danish Landrace (female) & & & \\
\hline SM & 11.54 & 11.10 & 11.00 \\
\hline $\mathrm{SE}$ & 0.85 & 0.41 & 0.30 \\
\hline Canadian Landrace (male) & & & \\
\hline SM & 10.55 & 11.00 & $9.75^{*}$ \\
\hline SE & 0.27 & 0.40 & 0.28 \\
\hline Canadian Landrace (female) & & & \\
\hline SM & & 9.25 & 9.08 \\
\hline 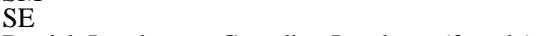 & & 0.64 & 0.54 \\
\hline Danish Landrace x Canadian Landrace (female) & & & \\
\hline SM & & 14.30 & $12.80^{*}$ \\
\hline SE & & 0.54 & 0.52 \\
\hline LB (cm) & & & \\
\hline Danish Landrace (male) & & & \\
\hline SM & 127.86 & 127.06 & $\begin{array}{r}126.00 \\
0.57\end{array}$ \\
\hline SE & 1.53 & 0.76 & 0.57 \\
\hline $\begin{array}{l}\text { Danish Landrace (female) } \\
\text { SM }\end{array}$ & & & \\
\hline $\begin{array}{l}\text { SM } \\
\text { SE }\end{array}$ & 126.00 & 125.50 & $\begin{array}{r}125.60 \\
0.60\end{array}$ \\
\hline Canadian Landrace (male) & 1.17 & 0.10 & \\
\hline SM & 125.29 & 125.40 & 125.30 \\
\hline $\mathrm{SE}$ & 0.44 & 0.70 & 0.70 \\
\hline Canadian Landrace (female) & & & \\
\hline & & 126.90 & 126.60 \\
\hline $\mathrm{SE}$ & & 1.28 & 1.11 \\
\hline Danish Landrace x Canadian Landrace (female) & & & 124.30 \\
\hline $\begin{array}{l}\mathrm{SM} \\
\mathrm{SE}\end{array}$ & & $\begin{array}{r}124.80 \\
0.74\end{array}$ & $\begin{array}{r}124.30 \\
0.58\end{array}$ \\
\hline
\end{tabular}


Our results indicate that the MC4R gene contributes to Days to $100 \mathrm{~kg}$, ADG and BF. The heterozygous genotype AG was favorable in LD breed. The significant effects of -1.43 (LD male) and -2.81 (LD female) for Days to $100 \mathrm{~kg}$ and of +61.17 (LD male) and +26.3 (LD female) for ADG were calculated.

The significant effects of the MC4R genotypes in LC breed were observed only for male LC. The difference of $0.8 \pm 0.38(\mathrm{p} \leq 0.05)$ for $\mathrm{BF}$ between genotypes AA and GG of LC male was calculated. We also found that the ADG and FI better in genotype GG (LC male) compared with genotypes AA and AG, but these differences were not significant. Effects of the GG genotypes on Days to $100 \mathrm{~kg}$, feed intake and backfat thickness were observed for female LC but they were not significant. The homozygous genotype GG was favorable in crossbred LD $\times$ LC. The significant effects of +74.2 for ADG and 1.5 for BF were calculated.

No significant effects of the MC4R genotypes on length body were observed for all breeds.

\section{DISCUSSION}

The identification of genes or genetic markers associated with growth, fat deposition and feed intake in pigs could have a great economic impact on pork production. Many polymorphic genes have been analyzed up to date including those for key hormones and their receptors (Hongyu et al., 2010; Yu et al., 2013; Oczkowicz et al., 2013; Huang and Wang, 2013; Ghaly and Al-Sowayan, 2014; Nanuwong and Bodhisuwan, 2014). The Melanocortin-4 Receptor (MC4R) is one of the most important signaling molecules involved in the conduct of the leptin signal and regulates energy homeostasis. Polymorphism of the MC4R gene leads to replacement of the amino acid sequence of the melanocortin-4 receptor. If the missense mutation p.Asp298Asn formed asparagine (Asn), this leads to blocking the leptin signal. Kim et al. (2000) were the first to publish information of the MC4R Asp298Asn polymorphism $\mathrm{A} / \mathrm{G}$ and found association with growth, fat deposition and feed intake in pigs.

Further was demonstrated by several studies a similar association of the Asp298Asn polymorphism of the MC4R gene with fatness and growth traits in pigs with different back-fat thickness and growth rate (Fan et al., 2009; Dvorakova et al., 2011; Munoz et al., 2011).

Our results indicate that heterozygous genotype AG (MC4R gene) was favorable in LD breed for Days to $100 \mathrm{~kg}$, ADG and BF. Thus, the partial blocking of leptin signal increases the rate of growth traits. On the other hand, the homozygous genotype GG could be more favorable for selection to improve the meat traits. According to the results shown above, GG genotype is associated with reduced backfat thickness in commercial crossbreds ( $\mathrm{LD} \times \mathrm{LC})$.

Therefore, can be noted that polymorphism Asp298Asn of the MC4R gene is associated with the growth traits and backfat thickness. Allele G, representing Asp298, conserved amino acids in the other subtypes of MCR, due to the smaller backfat thickness. Allele A, which is Asn298, is associated with more fat and best growth rate. Although allele A blocks the interaction the leptin receptor, melanocortin-4 receptor, while links with other hypothalamic neurons supported. As a result, the secretion of gonadotropins is not disturbed and at an elevated secretion leptin may even be activated. It is possible that the allele $A$ may be associated with reproductive characteristics in pigs. Future studies should pay attention to this issue.

\section{CONCLUSION}

The results of present study suggest that the MC4R gene contributes to Days to $100 \mathrm{~kg}$, ADG and BF. The heterozygous genotype AG was favorable in LD breed. The significant effects of -1.43 (LD male) and -2.81 (LD female) for Days to $100 \mathrm{~kg}$ and of +61.17 (LD male) and +26.3 (LD female) for ADG were calculated. The homozygous genotype GG was favorable in crossbred $\mathrm{LD} \times$ LC. The significant effects of +74.2 for ADG and 1.5 for BF were calculated.

Therefore, the data support a role for the MC4R Asp298Asn polymorphism in the genetic basis of economically important traits in pigs of Russia. Further research is needed to determine the effect of this gene on growth, meat and reproduction traits in pigs of different breeds and crosses.

\section{REFERENCES}

Benoit, S., M. Schwartz, D. Baskin, S.C. Woods and R.J. Seeley, 2000. CNS melanocortin system involvement in the regulation of food intake. Hormones Behav., 37: 299-305. DOI: 10.1006/hbeh.2000.1588

Dvorakova, V., R. Stupka, M. Sprysl, J. Cítek and M. Okrouhla et al., 2011. Effect of the missense mutation Asp298Asn in MC4R on growth and fatness traits in commercial pig crosses in the Czech Republic. Czech J. Anim. Sci., 56: 176-180. 
Fan, B., S.K. Onteru, M.T. Nikkila, K.J. Stalder and M.F. Rothschild, 2009. Identification of genetic markers associated with fatness and leg weakness traits in the pig. Anim. Genet., 40: 967-970. DOI: 10.1111/j.1365-2052.2009.01932.x

Gantz, I., T. Tashiro, C. Barcroft, Y. Konda and Y. Shimoto et al., 1993. Localization of the genes encoding the melanocortin-2 (adrenocorticotropic hormone) and melanocortin-3 receptors to chromosomes 18p11.2 and 20q13.2-q13.3 by fluorescence in situ hybridization. Genom., 18: 166167. PMID: 8276410

Ghaly, S.M.A. and S.S. Al-Sowayan, 2014. A high b1 field homogeneity generation using free element elliptical four-coil system. Am. J. Applied Sci., 11: 534-540. DOI: 10.3844/ajassp.2014.534.540

Hebebrand, J., A. Hinney, N. Knoll, A.L. Volckmar and A. Scherag, 2013. Molecular genetic aspects of weight regulation. Dtsch Arztebl, 110: 338-344. DOI: $10.3238 /$ arztebl.2013.0338

Hinney, A., C.I. Vogel and J. Hebebrand, 2010. From monogenic to polygenic obesity: Recent advances. Eur. Child Adolesc Psychiatry, 19: 297-310. DOI: 10.1007/s00787-010-0096-6

Hongyu, L., W. Tian, L. Zan, H. Wang and H. Cui, 2010. Mutations of MC4R gene and its association with economic traits in Qinchuan cattle. Mol. Biol. Rep., 37: 535-540. DOI: 10.1007/s11033-009-9706-0

Houston, R.D., N.D. Cameron and K.A. Rance, 2004. A Melanocortin-4 Receptor (MC4R) polymorphism is associated with performance traits in divergently selected large white pig populations. Anim. Genet., 35: 386-390. DOI: $10.1111 / \mathrm{j} .1365-$ 2052.2004.01182.x

Huang, Y.T. and M.S. Wang, 2013. The influence of the integrated model of social stratification structure on the public participating non-profit organizations. J. Soc. Sci., 9: 151-158. DOI: 10.3844/jssp.2013.151.158

Jokubka, R., S. Маак, S. Kerziene and H.H. Swalve, 2006. Association of a Melanocortin 4 Receptor (MC4R) polymorphism with performance traits in Lithuanian White pigs. J. Anim. Breed. Genet., 123: 17-22. DOI: 10.1111/j.1439-0388.2006.00559.x

Kalogeropoulos, N., 2013. Nilpotence and the generalized uncertainty principle (s). Am. J. Space Sci., 1: 99-111. DOI: 10.3844/ajssp.2013.99.111

Kesmanee, S., 2013. Thai literatures reflecting Chinese identity in Thai society. J. Soc. Sci., 9: 136-145. DOI: 10.3844 jssp.2013.136.145
Khan, M.A., R.K. Pandey, T. Nadeem, M.K. Sethi and S. Sharma et al., 2014. Complicated case of rheumatic heart disease; unexplored for years. OnLine J. Biol. Sci., 14: 44-48. DOI: 10.3844/ojbsci.2014.44.48

Kim, K.S., N. Larsen, T. Short, G. Plastow and M.F. Rothschild, 2000. A missense variant of the porcine Melanocortin-4 Receptor (MC4R) gene is associated with fatness, growth and feed intake traits. Mammalian Genome, 11: 131-135. DOI: 10.1007/s003350010025

Lisyova, J., J. Chandoga, S. Oravec, D. Kantarska and D. Bahmer, 2014. Case report of a patient with rare p.Arg136Cys (Apoe2*) mutation in apolipoprotein E gene. OnLine J. Biol. Sci., 14: 36-43. DOI: 10.3844/ojbsci.2014.36.43

Loos, R.J.F., C.M. Lindgren, S. Li, E. Wheeler and J.H. Zhao et al., 2008. Common variants near MC4R are associated with fat mass, weight and risk of obesity. J. Nat. Genet., 40: 768-775. DOI: 10.1038/ng.140

Maagdenberg, K.V.D., A. Stinckens, E. Claeys, M. Seynaeve and A. Clinquart et al., 2007. The Asp298Asn missense mutation in the porcine Melanocortin-4 Receptor (MC4R) gene can be used to affect growth and carcass traits without an effect on meat quality. Animal, 1: 1089-1098. DOI: 10.1017/S1751731107000456

Mountjoy, K.G., M.T. Mortrud, M.J. Low and R.B. Simerly et al., 1994. Localization of the Melanocortin-4 Receptor (MC4-R) in neuroendocrine and autonomic control circuits in the brain. Mol. Endocrinol., 8: 1298-1308. PMID: 7854347

Munoz, G., E. Alcazar, A. Fernandez, C. Barragan and A. Carrasco et al., 2011. Effects of porcine MC4R and LEPR polymorphisms, gender and Duroc sire line on economic traits in Duroc $\times$ Iberian crossbred pigs. Fuel Energy Abstracts, 88: 169-173. DOI: 10.1016/j.meatsci.2010.12.018

Nanuwong, N. and W. Bodhisuwan, 2014. Length biased beta-pareto distribution and its structural properties with application. J. Math. Stat., 10: 49-57. DOI: 10.3844/jmssp.2014.49.57

Oczkowicz, M., A. Mucha, M. Tyra, K. Ropka-Molik and K. Piorkowska, 2013. Lack of the associations of the polymorphisms in IGF2, MC4R and GNAS genes with reproduction traits in pigs and imprinting analysis of IGF2 gene in ovary and cornus uteri. Reproduct. Domest. Anim., 48: 562-568. DOI: 10.1111/rda.12125 
Ovilo, C., A. Fernandez, M.C. Rodríguez, M. Nieto and L. Silio, 2006. Association of MC4R gene variants with growth, fatness, carcass composition and meat and fat quality traits in heavy pigs. Meat Sci., 73: 42-47. DOI: 10.1016/j.meatsci.2005.10.016

Park, H.B., O. Carlborg, S. Marklund and L. Andersson, 2002. Melanocortin-4 receptor (MC4R) genotypes have no major effect on fatness in a Large White $\times$ Wild Boar intercross. Anim. Genet., 33: 155-157. DOI: 10.1046/j.1365-2052.2002.00824.x

Piorkowska, K., M. Tyra, M. Rogoz, K. Ropka-Molik and M. Oczkowicz et al., 2010. Association of the Melanocortin-4 Receptor (MC4R) with feed intake, growth, fatness and carcass composition in pigs raised in Poland. Meat Sci., 85: 297-301. DOI: 10.1016/j.meatsci.2010.01.017

Switonski, M., M. Stachowiak, J. Cieslak, M. Bartz and M. Grzes, 2010. Genetics of fat tissue accumulation in pigs: A comparative approach. J. Applied Genet., 51: 153-168. DOI: 10.1007/BF03195724
Tenesa, A., H. Campbell, E. Theodoratou, L. Dunlop and R. Cetnarskyj et al., 2009. Common genetic variants at the MC4R locus are associated with obesity, but not with dietary energy intake or colorectal cancer in the Scottish population. Int. J. Obes (Lond), 33: 284288. DOI: $10.1038 /$ ijo.2008.257

Wan, Y., Y. Zhang, P. Ji, Y. Li and P. Xu et al., 2012. Molecular characterization of CART, AgRP and MC4R genes and their expression with fasting and re-feeding in common carp (Cyprinus carpio). Mol. Biol. Rep., 39: 2215-2223. DOI: 10.1007/s11033011-0970-4

Yu, K., L. Getmantseva and N. Shirockova, 2013. Sheep Breeding resources in Rostov region, Russia. World Applied Sci. J., 23: 1322-1324. 